\title{
Erratum to: Gender Difference in Sleep Problems: Focused on Time Use in Daily Life of Korea
}

\author{
Seung-Eun Cha $\cdot$ Ki-Soo Eun
}

Published online: 13 November 2014

(C) Springer Science+Business Media Dordrecht 2014

\section{Erratum to: Soc Indic Res (2014) 119:1447-1465 DOI 10.1007/s11205-013-0550-1}

After the article has been published online first, the author discovered that the one of the reference had misspelling. The book of Jonathan Gershuny (2000) should be "Gershuny (2000)", not Gershuney (2000). Authors apologize to readers and especially Jonathan Gershuny himself for the misprinting the name of the reference.

The online version of the original article can be found under doi:10.1007/s11205-013-0550-1.

\section{S.-E. Cha $(\square)$}

Department of Child, Family and Welfare, The University of Suwon, 17 Wau-an gill, Boungdam-up, Hwasung-si, Gyounggi-do 445-743, Korea

e-mail: secha@suwon.ac.kr

\section{K.-S. Eun}

Graduate School of International Studies (Korean Society \& Culture), Seoul National University, 1 Gwanak-ro, Gwanak-gu, Seoul 151-742, Korea

e-mail: eunkisoo@snu.ac.kr 